\title{
The Challenges of Print Media Journalism in the Digital Era
}

\author{
M. Yoserizal Saragih ${ }^{1}$, Ali Imran Harahap ${ }^{2}$ \\ ${ }^{1,2}$ State Islamic University of North Sumatera (UINSU), Medan, Indonesia \\ yosesaragih77@gmail.com
}

\begin{abstract}
This study aims to analyze the challenges of print media journalism in the digital era. The development of online media has now become a threat to newspapers and print media. The rapid development of the internet has encouraged people to access online media easily through mobile phones, or gadgets. Print media are in danger of being threatened, and loyal readers of print media are likely to turn to online media. The results shows that the biggest challenge of journalists in the digital information era is synonymous with the competition between media mainstream and new media in this case online media. The party who felt a significant impact with the presence of online media was journalism which of course already had a new channel to spread information and news.
\end{abstract}

Keywords

journalism print media; digital

era

\section{Introduction}

The digital era can be said to have an influence on all fields of human life, not least journalism. The rapid development of the internet has encouraged people to access online media easily through mobile phones, or gadgets. Print media are in danger of being threatened, and loyal readers of print media are likely to turn to online media. The reality threatens print media publishers, but print media have a distinctive character, namely: clear, complete and detailed news, besides that for centuries, print media has accompanied the development of human civilization, so it is not easily forgotten. Online media are fast, up-todate and continuous, but this news can only be accessed using sophisticated tools and not all people have the tools and understand the technology.

The print media, although in terms of numbers, have increased significantly in terms of readers. Data from the Central Statistics Agency shows that residents aged 10 years and over who read newspapers amounted to $23.0 \%$. In 2006 it decreased by $0.3 \%$. Drastic decline occurred in 2009 where newspaper readers declined to $18.4 \%$ and in 2012 fell again by $17 \%$. This means that in the context of readers and the market, print media coverage decreases and of course, it will eventually cause the press industry to close down. The phenomenon of online media which is predicted to replace print media also continues to increase in Indonesia. Data from the Central Statistics Agency showed that in 2005 internet users in Indonesia only reached 3.34 percent. The number of internet users experienced a significant increase to $35.64 \%$ in 2014 . This means that within a period of nine years there was a tenfold increase. Of course this contributes to the future of print media.

The internet opens a public space for citizen participation, whether professional or amateur in information dissemination. Information is no longer exclusive to journalists and the media. Journalistic work is now also carried out by the public. This is the era called Alvin Toffler, 1980s futurologist as the era of consumption (production and consumption). The public can become producers and consumers of information. Stephen J.A. Ward, professor of 
journalism ethics at the University of Wisconsin Madison, in his article Digital Media Ethics, noted that the presence of the internet made today's professional journalists share space with Twitter, bloggers, citizen journalists, and social media users. History records, new media is always present along with technological developments. The internet makes humanity like living in a global village (global village). The internet as a medium has also influenced the way we live, including the way we produce and consume news.

In his 2006 book The Vanishing Newspaper, Philip Meyer predicted that in 2044 there would be only one newspaper copy. The future of newspapers has become a big question in the midst of the onslaught of TV, radio and even the internet. A number of surveys indicate that the position of newspapers is being eroded by online media penetration.

There are several aspects of mass media that make themselves important so that displaying works and ideas through mass media is a strategic thing. First, a very broad reach in disseminating information that is able to cross borders (geographical), age groups, gender, social status, freedom (demographic) and differences in understanding and orientation (psychographic). Second, the ability of the media to multiply extraordinary messages. Third, every mass media can discuss an idea or work according to their respective views. Fourth, with its agenda setting function, the mass media have ample opportunity to share one's ideas or work.

The freedom and responsibility of message content as communication ethics is sometimes still contradictory in its implementation. In philosophy, the notion of freedom is the ability of humans to determine themselves. Freedom is more positive and it exists as a consequence of human potential to be able to think and will. It has become human nature to be a being who has freedom, is free to think, will and do. The definition of responsibility is the ability of humans who realize that all their actions always have consequences.

\section{Review of Literature}

\subsection{Journalistic Concepts}

Journalism in its sense, comes from the word "jour" (French) which means "diary". Since ancient Roman times, Julius Caesar, has known the word "Acta Diurma". Which means all activities from day to day (government announcements, etc.). The term journalism at this time, may already be familiar to the ear. In this current era, various information and telecommunication media greatly influence people's attitudes and behavior, especially in urban areas, even the mass media can influence people to remote rural areas. In terms of its origin, the term journalism comes from journalistiek (Dutch), similar to the term in English namely Journalism which originates from the words of the journal, which is a translation of the Latin diurna which means "daily" or "every day", where all the news on that day contained in printed sheets of paper.

In the Indonesian Dictionary, it is stated that journalism is the work of collecting, writing, editing and publishing news in newspapers and so on, which involves journalism and message. Journalism according to Onong U. Effendi, journalism is managing news from getting material to disseminating it to the public. Initially journalism only managed things that were informative. That was proven by Acta Diurma as the first journalist product in ancient Roman times, when the emperor Julius Caesar came to power.

Understanding the term journalism can be reviewed from three points of view: 1) Harfiyah, 2) Conceptual / Theoretical, 3) Practical. In harfiyah, journalistic means journalism or authorship. The basic word "journal", means report or note, or "jour" in French which 
means "day". The origin of the journalistic word from Ancient Greek, "du jour" which means day, that is, today's events which are reported in printed sheets. Conceptually, journalism can be understood from three points of view: a) Prose, b) Engineering, c) Science. As a process, journalism is the "activity" of searching, processing, writing, and disseminating information to the public through the mass media. This activity is carried out by journalists. As a technique, journalism is "expertise" or "skills" writing journalistic work (news, articles, and features) including expertise in collecting writing material such as reporting events and interviews.

\subsection{News}

News is an event report that has journalistic value or has news values - actual, factual, important, and interesting. News is also called "latest information". Types of news include: a) Direct news (Straight News / Spot News / Hard News), b) opinion News, c) Investigative news, d) Soft News. Views are views or opinions about an issue or event. This type of information includes columns, editorials, articles, reader letters, caricatures, corners, and essays. There are also writings that do not include the news also cannot be called opinions, namely features, which is a combination of news and views. The most popular types of features are feature tips (how to do it features), biographical features, travel / adventure notes, and human interest features.

Specifically, the language of journalism can be distinguished according to its form, namely the language of newspaper journalism, the language of tabloid journalism, the language of magazine journalism, the language of broadcast radio journalism, the language of television journalism, and the language of internet online media journalism. The language of newspaper journalism, except to be subject to general rules or principles of journalistic language, also has very specific or specific characteristics. This is what distinguishes him from other media journalistic languages. There are seventeen main features of journalistic language that apply to all forms of periodical media, namely: Simple, Brief, Solid, Simple, Clear, Attractive, Democratic, Populist, Logical, Grammatical, Avoiding speech, Avoiding foreign words and terms, Choice of words (diction) is right, Prioritizing active sentences, Avoiding words or technical terms, Subject to ethical principles.

\subsection{Print Media as Mass Media}

Print media is the oldest media available on earth. Print media originated from the media called Acta Diuna and Acta Senatus in the Roman Empire, then developed rapidly after Johanes Guttenberg invented the printing press until now has various forms, such as newspapers, tabloids, and magazines. Print media are all printed goods that are used as a means of delivering messages as mentioned previously, various print media in general.

In addition according to Suharyanto (2018) the message that must be delivered must be paid, in the advertisement also occurs the process of identifying the sponsor. Advertisements not only display messages about the greatness of the products offered, but also convey a message so that consumers are aware of the companies that produce the products offered.

The history of modern media begins with printed books. Although initially the book printing effort was only an attempt to use technical tools to produce the same or almost the same text, which had been copied in large numbers, but that effort could of course still be called a kind of revolution. Gradually the development of printed books underwent changes in terms of content increasingly secular and practical. Then more and more popular works, especially in the form of political and religious brochures and pamphlets written in local 
languages, played a role in the process of medieval transformation. So, at the time of the revolution in the book community also played a role that cannot be separated from the revolution process itself.

It was almost two hundred years after the discovery of the printing press that what we now know as a prototype newspaper can be distinguished from circulars, pamphlets, and news books of the late sixteenth and seventeenth centuries. In reality it is evident that it is the letter which is the initial form of the newspaper, not the book shaped sheet. Circular circulated through the postal service that has not been perfect and its role is mainly to disseminate news regarding events related to international trade. So, the emergence of a newspaper is the development of a longstanding activity in the world of diplomacy and the business environment. Early newspapers were marked by: a permanent form; commercial nature (sold freely); aiming a lot (giving information, taking notes, presenting hypertension, entertainment, and rumors); public and open.

In the concept of understanding above, print media (newspapers and magazines) have a higher level of innovation than printed books - inventions of new forms of writing, social and culture - although at that time the views that appeared were not so. The specialty of newspapers, when compared to other means of cultural communication, lies in individualism, orientation to reality, usability, secularity (values), and their compatibility with the demands of the needs of new social classes, namely the needs of urban entrepreneurs and professionals. The quality of the newness lies not in the technological elements or the way of its distribution, but in its function that is appropriate for certain social classes in a changing climate of life and an atmosphere that is more permissive (openly) socially and politically. The history of the development of newspapers and magazines can then be described as a series of struggles, progress and repetition, leading to a climate of freedom, or it can also be seen as a continuation of the history of economic and technological progress. Important elements in press history that affect the boundaries of modern newspapers and magazines will be presented in the following paragraphs. Indeed the history of the development of the press of each nation cannot possibly be explained in one brief presentation. Apart from that, it should be noted that these important elements, which often mingle and interact with each other, are the deciding factors in the development of press institutions. Of course, with different levels of influence.

Each media has its own advantages, print media also has advantages compared to electronic media. The advantage of print media in general compared to electronic media lies in the "durability" of information. Of the various types of mass media, print media has advantages that are not shared by other media. The printout is permanent and can be stored so that the reader can repeat it until it understands the contents of the message being delivered, at no additional cost. In addition, print media pages, according to Mondry, can continue to be added if needed.

According to Wahyudin the advantages of print media are as follows: 1) Can be read many times by saving it. 2) Can make people think more specifically about the contents of the writing. 3) Can be stored or collected the contents of the information. 4) The price is more affordable and in its distribution. 5) Better able to explain things that are complex or rigid.

There are two types of print media that develop in the middle of society, namely newspapers and magazines. Both of these print media have advantages, namely:

The advantages of newspapers are: 1) Usually relatively inexpensive. 2) Flexible (more flexible in determining the publication schedule of advertisements and newspapers that publish (whether local, regional or national) related to the audience targeted by the ad). 3) 
Can be enjoyed longer. 4) Market coverage; newspapers are able to reach urban areas according to their area. 5) Comparison shopping; newspapers are often used as a reference or reference for consumers in buying goods or services. 6) Positive consumer attitude; the actuality of the information conveyed is also used as a reference for the reader.

While the advantages of magazines are as follows: 1) Can be enjoyed longer (long life span) The reading is more selective. 2) Can express an interesting picture (Visual Quality). 3) Target audience; one of the advantages of a magazine when compared to other media is its ability to reach certain specialized market segments. 4) Public acceptance; the ability to lift the advertised products is in line with the target audience's perception of the magazine's prestige.

The shortcomings of Print Media are: 1) In terms of time the print media is slow in providing information. Because print media cannot disseminate news directly to the public and must wait for print. 2) Print media can only be in the form of writing. 3) Just print media can provide visuals in the form of images that represent the entire contents of the news. 4) Production costs are quite expensive because the print media must print and send it before it can be enjoyed by the public.

Then the shortcomings of newspapers are: 1) Easy to ignore \& stale quickly. 2) Short life span; although its reach is broad and mass and can be documented, newspaper readers only need about 15 minutes to 30 minutes to read it and generally only read it once. 3) Clutter; If the contents and layout are chaotic it will affect the meaning and understanding of the contents of the advertising message by the reader. 4) Limited coverage of certains group; certain groups cannot be reached by newspapers, for example the lower middle class community or people under 15 years of age. 5) Products that don't fit; some products cannot be advertised using newspapers because they require demonstration or require certain considerations. Example of sports equipment advertising. 6) The type of material used is usually easy to tear, meaning that high mechanical interference, so the information received is incomplete.

Also deficiencies Magazine is: 1) The cost is relatively expensive. 2) Low flexibility (limited). 3) Distribution. Many magazines are circulating so slow that they only pile up on store shelves. There are also magazines that don't have the right distribution network. 4) In certain areas with high purchasing power but difficult to reach, magazines are often absent. 5) The type of material used is usually easily torn, meaning that high mechanical interference, so the information received is incomplete.

\section{Discussion}

Islam was actually born with a conception of human relations based on justice or the development of online media has now become a threat to newspapers and print media. The rapid development of the internet has encouraged people to access online media easily through mobile phones, or gadgets. Print media are in danger of being threatened, and loyal readers of print media are likely to turn to online media. This reality indeed threatens the print media publishers, but the print media has a distinctive character namely: clear, complete and detailed news, besides that for centuries, print media has accompanied the development of human civilization, so it is not easily forgotten. Online media are fast, up-to-date and continuous, but this news can only be accessed using sophisticated tools and not all people have the tools and understand the technology. Nevertheless, the print media has anticipated early by making online media to accompany the published print media. 
The declining trend of print media and the replacement of digital media explosion can be seen in the results of Galarneau and Joseph's research, which shows that consumer magazine publishers gather at the American Magazine Publisher at the 5th Digital Conference in New York on March 3, 2009. That the trend of print media is declining and participants heard about the explosion of digital media in the magazine industry. The discussion included discussing how to better utilize the website, bridging the division between editorials and businesses, new product trends, and strategic planning, marketing and advertising on the Internet. Began to shift the habit of consumers to consume new media using an internet connection and start leaving traditional media poses a threat to the sustainability of print media. Even though online media cannot yet be accessed by all groups because there are still some areas with limited internet connections, print media still anticipate the presence of online media by making various efforts, one of which is media convergence.

Resmadi and Yuliar, revealed that media convergence is one of the mass media developments involving many technological factors in it. The presence of the internet has encouraged mass media to apply the concept of media convergence such as online media, epaper, e-books, radio streaming, social media. Competition in the media business is one of the factors driving the mass media to apply this concept because technological development does not rely solely on print formats (newspapers, magazines, books) alone. Media convergence innovation is needed so that mass media are able to remain competitive in today's business era. As one form of innovation, media convergence requires various processes and stages in its application. Research by Resmadi and Yuliar traces the process of diffusion of media convergence innovation with the object of daily research of the People's Mind, to illustrate how media convergence can be adopted gradually by a mass media.

Some experts have predicted the fall of print media. As written by Supadiyanto, a number of world figures have predicted the emergence of paperless newspaper technology. These figures are Roger F. Fidler, Bill Gates, Rupert Murdoch, and Philip Meyer. There are four implications of the increasingly widespread use of tablet newspaper or paperless newspaper technology in the mass media industry in Indonesia. First, the direct implication is the massive transfer of technology from print media to the paperless newspaper business base which is very inexpensive in terms of procurement of production costs and distribution throughout the world. Second, another direct implication is that there is a change in the orientation and lifestyle of the community in accessing mass media from the beginning which is still conventional, by opening sheet after sheet; switch to pressing a button or pressing the monitor screen. Third, the implications for media content will be more varied; because it reaches areas that are not insulated by country / territory boundaries. Fourth, other main implications are that various mass media companies increasingly integrate multimedia networks; so that there is multimedia convergence. Fifth, another implication is that conventional print media companies will automatically go out of business.

Indonesian print media is still at the stage of adopting media convergence. Print media are trying to improve content and have not yet thought about business development strategies. The positive side of digital technology is that it can open access and increase public participation in the dissemination of information and supervision of democratic governance. The benefit obtained from the conversion and convergence of these media is the occurrence of efficiency in the costs of production and distribution in addition to a wider range without any regional restrictions. 
The emergence of the internet provides opportunities for non-journalists (citizen journalists) to publish their articles in this new media. This is a big change along the history of journalism where the internet channel has shifted the position of journalists in line with the audience who become reporters. When talking about the contribution of citizen journalists themselves, it can be seen from various events in the hemisphere whose information dissemination actually comes from citizen blogs in this case acting as citizen journalists. Seth Hettena, a correspondent for The Associated Press in San Diego who writes about the military feels the important role of the contents of people's personal blogs and web content for the sake of its coverage.

In Indonesia, citizen journalism is arguably already beginning to develop and its usefulness is felt when there are major events such as terrorist attacks and natural disasters. since the 2002s, citizen media has grown rapidly trying to find existence in the midst of the atmosphere of traditional media. With the internet, citizen media is able to disseminate information in the form of text, audio, video, photos, comments and analysis. Even able to perform press functions such as watchdogs, information filters, fact checking and even editing.

Allan emphasized that Citizen Media has become a new trend that should get the attention of traditional media, including in Indonesia. He observed, with his worries and fears, traditional media (including print media) began to learn how to change their journalism concept from an authoritarian approach to a top-down approach in order to compete in this new era, including one of the strategies to stay close to their audience. Then what is the future of citizen media? It is undeniable that citizen journalism will become a frustrating concept for the mainstream media because its function and development continues to attract the attention of its own citizens.

To be able to stay afloat, print media must be able to maintain credibility and trust in the information presented. This credibility and trust of the community can only be built by the spirit of professionalism of journalists who adhere to the ethics of journalism, which is to present factual information that is well verified. This is a strong offer for print media to be able to survive. Jarvis in Sugiya said that the media industry, especially print media, must make changes if it does not want to be marginalized. One of them is a change in strategy must be made so that print media can survive. Print media must be able to define itself from the medium. Print media cannot be just paper. Strength and value do not only come from content control and distribution. Another strategy carried out by print media is by integrating newspaper content into electronic tablets.

Newspaper (print) and online media have their strengths and weaknesses. Newspapers seem slow, because information that has been bombarded through television and online media can only be enjoyed by readers the next day. As for online media, they have the advantage of being fast and complete. For example: detik.com which delivers information quickly and up to date 24 hours continuously, as well as online media that deliver the fastest news about natural disaster warnings compared to print media. Weaknesses online media, among others, about the accuracy of the news. Even though online media is developing quite rapidly and print media are predicted to fall in Western countries, but in the context of Indonesia print media can still survive. This is proven by the existence of print media where there was an increase in the number of new print media in 2014 compared to the previous year. The tendency of print media in Indonesia is also able to adapt to the convergence of print media to online media, without leaving the print media's existence. Thus it becomes 
interesting to study and study more deeply how the media in Indonesia related to the future of print media in facing the onslaught of online media.

If you are talking about solutions, you must look at the impact of online media on print media. Of course, with the inevitability of the digital age, print media journalists must be able to see the positive side of online media for print media. The positive impact of online media on print media is: First, can be a print media partner in delivering messages, with efficiency and speed of time, in penetrating and delivering news published by a media. Second, reducing wasteful use of paper, in this case cutting trees specifically for paper. Third, save costs and do not require a lot of movement, just click then the news has been read.

Online journalism and conventional journalism (print media) are indeed journalisms that have very basic differences, both from the media used, the actors or workers in them, to the composition and appearance of messages that are also different, but both have advantages and disadvantages of each. Its existence cannot be said as a media that opposes or competes with each other, but also as a medium that can complement each other in journalistic activities or in the world of journalism. The presence of the two types of journalism in essence has the same goal, which is trying to meet the needs or present information or news that is important to the public or wide audience. However, the way, the system used is different, as well as its presentation, making the two journalisms seen as a journalism or media journalism that is competing with each other or competing. In conventional journalism, journalists are also required to have the ability / sensitivity to the situations and conditions that occur in the field. The struggle and the process carried out in searching, processing to disseminating news is also not as easy and simple as what happens in online journalism.

The positive impact of this technological development can require journalists to be more enthusiastic and able to master a variety of applications to support the increasingly varied information needs of society. Journalists are required to have several other skills besides being able to only write news. This can be used as motivation for journalists to continue to innovate. Perhaps another positive impact of social media is that social media can also be used as a place to promote a variety of journalistic products easily and cheaply. Everything certainly has advantages and disadvantages, one of which is social media.

\section{Conclusion}

The biggest challenge of journalists in the digital information era is synonymous with the competition between media mainstream and new media in this case online media. The party who felt a significant impact with the presence of online media was journalism which of course already had a new channel to spread information and news. Traditional media which at its birth did not use internet channels in the practice of news production now inevitably have to follow the flow of online media if they do not want to be abandoned by their audiences.

A new type of journalism that emerged, namely online journalism which was followed by the development of citizen journalism, has made the mainstream media worry about its existence, although not many traditional media are open to new concepts.

To survive, conventional media must be able to maintain credibility and trust in the information presented. This credibility and trust of the community can only be built by the spirit of professionalism of journalists who adhere to the ethics of journalism, which is to present factual information that is well verified. This is a strong offer for print media to be able to survive. The media industry, especially print media, must make changes if it does not 
want to be marginalized. One of them is a change in strategy must be made so that print media can survive. Print media must be able to define itself from the medium. Print media cannot be just paper. The strength and value do not only come from content control and distribution. Another strategy carried out by print media is by integrating newspaper content into electronic tablets.

\section{References}

Amar, M.Djen, 1984, Hukum Komunikasi Jurnalistik, Bandung: Alumni

Aw, Suranto, 2010, Komunikasi Sosial Budaya, cet pertama, Yogyakarta: Graha Ilmu

Departemen Pendidikan Nasional, 2003, Kamus Besar Bahasa Indonesia, cet ke III, Jakarta: Balai Pustaka

Effendy, Onong Uchana, 1984, Dimensi-Dimensi Komunikasi, Bandung: Alumni

Kurniawan, Junaedhie, 1991, Ensiklopedi Pers Indonesia, Jakarta: Gramedia Pustaka Utama

Kurniawan, Moch., 2006 Jurnalisme Warga: Prospek dan Tantangannya. Sosial Humoniora. Vol. 11. No. 2.

Kusuma, Satria, 2016, Posisi Media Cetak Di Tengah Perkembangan Media Online Di Indonesia, Jurnal Prodi Ilmu Komunikasi, Unika Atma Jaya, Vol.5, No.1.

McQuail, Denis, Teori Komunikasi Massa, Edisi Kedua, Jakarta: Penerbit Airlangga

Mondry, 2008, Pemahaman Teori dan Praktik Jurnalistik, Cet. Pertama, Bogor Selatan: Ghalia Indonesia

Nurkinan, 2017, Dampak Media Online Terhadap Perkembangan Media Konvensional, Jurnal Politikom Indonesiana, Vol. 2 No. 2

Palapah, M.O dan Atang Syamsuddin, 1975, Studi Ilmu Publisistik, Bandung : Fakultas Publisistik UNPAD

Resmadi, Idhar dan Sonny Yuliar, 2014, Kajian Difusi Inovasi Konvergensi Media di Harian Pikiran Rakyat, Jurnal Sosioteknologi, Vol. 13 No. 2

Suharyanto, A., Hidyat, T. W. (2018). Revealing Medan's Chinese Ethnic Identity in Advertising Grief at Harian Analisa Newspaper. Budapest International Research and Critics Institute (BIRCI-Journal), 1 (4); 83-92.

Wahyudin, 2016, Pengantar Jurnalistik Olahraga, Makassar: Fakultas Ilmu Keolahragaan Universitas Negeri Makassar 